http://dx.doi.org/10.18778/1508-1117.25.05

Tomasz Figlus

\title{
PROBLEM OSAD ZAGINIONYCH NA GRUNCIE BADAŃ GEOGRAFICZNO-HISTORYCZNYCH PRÓBA KONCEPTUALIZACJI TEORETYCZNEJ I WYBRANE ZAGADNIENIA METODYCZNO-EMPIRYCZNE
}

Zarys treści W artykule dokonano konceptualizacji teoretyczno-metodycznej zagadnienia zaniku osadnictwa. Ujawniony na etapie analizy stanu badań geograficzno-historycznych chaos terminologiczny stanowił dla autora asumpt do próby usystematyzowania stosowanych pojęć oraz zaproponowania jednoznacznych definicji. Wśród ogółu osad zaginionych wydzielono dwie podstawowe kategorie: osad zaginionych de facto, w których doszło do całkowitego przerwania ciągłości osadniczej, czyli opustoszenia wskutek ekstremalnych zjawisk przyrodniczych, reperkusji wojen i klęsk elementarnych oraz przemian struktury gospodarczej. Wyszczególniono również typ osad zaginionych pozornie (de iure), w przypadku których mamy do czynienia z zanikiem nazwy własnej w wyniku prawno-administracyjnych procesów konsolidacji osadnictwa, inkorporacji do pobliskich miejscowości lub zjawiska denominacji. W kontekście zaprezentowanych wyników badań empirycznych omówiono wybrane problemy metodyczne związane z dostępnością materiału źródłowego, sposobami ustalenia metryki historycznej i długotrwałości zaniku osadnictwa, identyfikacji zjawiska sukcesji osadniczej terenów podlegających czasowo całkowitej depopulacji, określenia okoliczności opustoszenia oraz dokładnej lub przybliżonej lokalizacji osad zaginionych.

Słowa kluczowe Osady zaginione, pustka osadnicza, geografia historyczna, osadnictwo wiejskie.

\section{Wprowadzenie}

Rozwój historyczny osadnictwa w przestrzeni geograficznej stanowi niezwykle istotny aspekt badań odnoszących się do rekonstrukcji krajobrazu kulturowego. Procesy zasiedlenia zachodziły wieloetapowo i uwarunkowane były na 
danym obszarze wieloma determinantami przyrodniczymi, prawno-politycznymi, społeczno-kulturowymi i gospodarczymi. Zróżnicowany udział i zakres oddziaływania tych czynników decydował o zmienności rozwoju sieci osadniczej, mógł wpływać dodatnio na tworzenie kolejnych punktów osadniczych lub w odpowiednich okolicznościach hamować procesy kolonizacji wewnętrznej (Arnold 1951; Tyszkiewicz 2014). Warto w tym kontekście spostrzec, że rozwój osadnictwa ma charakter dynamiczny. Nie polega jedynie na wzroście ekumeny poza tereny do tej pory niezasiedlone i niezagospodarowane oraz stałym zagęszczeniu sieci osadniczej obszarów już zamieszkanych. Mamy bowiem do czynienia ze swoistą fluktuacją rozwojową osadnictwa. Oprócz wyraźnych etapów ekspansji wyróżnić można bowiem także fazy regresywne, wyrażające się w depopulacji i zaniku istniejących wcześniej osad. Zjawiska te uwarunkowane są wieloma czynnikami natury zarówno egzo-, jak i endogenicznej i są na stałe wpisane w rozwój krajobrazu kulturowego, ujawniając się w różnych skalach przestrzennych i czasowych. Podobnie jak możemy obserwować powstawanie nowych punktów osadniczych oraz ich wielostopniową ekspansję, równie często spotykamy przypadki sukcesywnego lub nagłego kurczenia się i zaniku osadnictwa. Są to procesy uniwersalne, współwystępujące synchronicznie, a ich efektem jest kształtowanie sieci osadniczej danego obszaru na przestrzeni dziejów.

Powstawanie pustek osadniczych stanowi niezwykle interesujący problem badawczy, odnajdujący odzwierciedlenie w studiach analitycznych, zarówno w aspekcie teoretyczno-metodycznym, jak i empirycznym. Geohistoriografia $\mathrm{w}$ tym zakresie nie jest jednak zbyt imponująca. Zagadnienie to doczekało się co prawda pewnej grupy opracowań w badaniach geograficzno-historycznych i archeologicznych, głównie w zachodniej Europie, lecz ujawnia się przy tym mnogość różnych podejść badawczych, skutkująca niejednoznacznością bazy terminologicznej oraz zakresem stosowanych procedur analitycznych. Polskie badania na temat zaniku osadnictwa na tym tle wypadają jeszcze gorzej. Oprócz przyczynkarskich studiów w tym zakresie brakuje badań porównawczych, kompleksowo odnoszących się do omawianej problematyki. Panuje przy tym duży chaos $\mathrm{w}$ aspekcie rozumienia podstawowych pojęć i rozwiązań metodycznych. W tym kontekście uzasadniona jest konceptualizacja na gruncie polskim zagadnienia osad zaginionych, bazująca na rodzimym i obcym piśmiennictwie. Zasadniczym celem niniejszego artykułu jest zatem podjęcie próby systematyzacji i uściślenia pojęć w świetle literatury przedmiotu oraz zebranego materiału źródłowego. Autor, chcąc przybliżyć problematykę tzw. osad zaginionych oraz ich sukcesji, postara się zaproponować spójne ujęcie teoretyczne oraz wskazać na różne problemy metodyczne w aspekcie identyfikacji, ustalenia lokalizacji oraz przyczyn zaniku osadnictwa. 


\section{Przegląd badań w zakresie problematyki zaniku osadnictwa w Europie}

Występowanie osad zaginionych stanowi zjawisko obserwowane od czasów najdawniejszych aż po czasy współczesne, wykazujące przy tym duże zróżnicowanie przyczynowo-skutkowe. Najwcześniej problem ten znalazł odzwierciedlenie w historiografii niemieckiej. Kwestia pustek przez długi czas ujmowana była na marginesie szerszych badań regionalnych nad dziejami osadnictwa. Pionierskie badania $\mathrm{w}$ tym zakresie zainicjował $\mathrm{w}$ okresie międzywojennym K. Scharlau (1933, 1938). Historyk ten przeprowadził kompleksowe analizy porównawcze, czego efektem była próba zdefiniowania pustek oraz dokonania ich klasyfikacji. Warto podkreślić, że przypisał on zanikowi osadnictwa dość szerokie znaczenie. Do pustek (Wüstungen) zaliczył zarówno całkowicie, jak i częściowo opuszczone jednostki osadnicze, o istnieniu których w przeszłości świadczą informacje pochodzące ze źródeł dokumentowych, zachowane struktury toponimiczne, pozostałości archeologiczne lub chociażby elementy ustnej tradycji. Rozróżnił on ponadto pustoszenie obszarów koncentracji zabudowy z uwzględnieniem obiektów mieszkalnych i gospodarczych (Ortswüstung) od zaniku zagospodarowania układów gruntowych (Flurwüstung). Zjawisko powstawania pustek może zatem odnosić się niezależnie do obu komponentów morfologicznych, czyli siedlisk oraz sprzężonych z nimi rozłogów. Możemy mieć także do czynienia z pustoszeniem całej osady wraz z towarzyszącymi jej polami (Dorfwüstung). Co istotne, w każdym z wymienionych przypadków może zajść sytuacja częściowego zaniku (partielle Wüstung) lub całkowitego (zupełnego) opustoszenia (totale Wüstung). Oprócz kryterium zasięgu przestrzennego zaniku osadnictwa, K. Scharlau uwzględnił także efektywność czasową zaniku jako czynnik różnicujący pustki w postaci kryterium chronologicznego. Wydzielił bowiem osady okresowo zaginione (temporäre Wüstung), czyli takie, które po opustoszeniu zostały relokowane w ramach późniejszej sukcesji osadniczej oraz osady, które zaginęły w sposób absolutny, tj. bezwzględny czasowo (permanente Wüstung) i już nigdy się nie odrodziły. Klasyczne już dziś podejście terminologiczno-klasyfikacyjne zaproponowane przez K. Scharlaua, mimo uwag krytycznych, było wielokrotnie cytowane i stało się inspiracją do dalszych badań w tym zakresie. W tym kontekście szczególnie wyróżnia się W. Abel $(1943,1967)$ i jego dorobek naukowy. Pustki osadnicze postrzegał on jako tereny z różnych względów wtórnie niezasiedlone lub też będące obszarem czasowego opustoszenia. Mimo, że stan zaludnienia uznawany był jako czynnik zasadniczy z punktu widzenia powstawania pustek, to badacze Ci ograniczali się przede wszystkim do osadnictwa średniowiecznego. Pomijano natomiast wiele zanikłych komponentów osadnictwa nowożytnego, w których zachowały się np. ruiny zamków czy materialne relikty innych elementów zagospodarowania. Aspekt demograficzny w postaci depopulacji jest zatem w tym 
ujęciu niewystarczający, gdyż musi uwzględniać także całkowity zanik dawnej zabudowy i użytkowania gospodarczego. Taki pogląd może być jednak uznany za dyskusyjny, wywołujący uzasadnioną polemikę. $Z$ dotychczasowych rozważań ujawnia się także spojrzenie na zagadnienie pustek jako pojęcia o szerokim znaczeniu, gdyż obejmuje w zaproponowanym ujęciu także częściowe opustoszenie. Osady zaginione mogą stanowić zatem specyficzny typ pustek odznaczający się permanentnym zanikiem, abstrahując na tym etapie od długości jego trwania. Jest to zasadniczy wniosek, rozwinięty w dalszej części wywodu. Badania nad pustkami, w tym osadami zaginionymi, były kontynuowane w okresie powojennym w Niemczech m.in. przez H. Mortensena (1949), H. Pohlendta (1950), G. Leingärtnera (1956), A. Krenzlin (1959), W. Janssena (1968), M. Borna (1972, 1979), H. Jägera (1979), K. Fehna (1983) i D. Denecke (1985), którzy prowadząc studia w różnych skalach przestrzennych rozwinęli wyraźnie ten nurt badawczy, stosując przy tym często nowe rozwiązania metodyczne.

Odpowiedzi na pytania odnoszące się do identyfikacji, metod lokalizacji oraz ustalania relacji przyczynowo-skutkowych dotyczących zjawiska pustek osadniczych, w tym problemu tzw. osad zaginionych w rozumieniu całkowitego opustoszenia, poszukiwali także badacze francuscy, głównie skupieni wokół F. Braudela i środowiska naukowego szkoły Annales. Podejmowano w tym zakresie szereg badań o charakterze regionalnym, skutkujących wieloma przyczynkarskimi opracowaniami na ten temat, czego przykładem są chociażby prace G. Démians d'Archimbaud (1965) i N. Coulet (1973) o osadach zaginionych regionu Aix-en-Provence oraz A. Humma (1971) traktujących o pustoszeniu osad Dolnej Alzacji. Przełomowym niewątpliwie wydarzeniem była trzecia międzynarodowa konferencja historyków gospodarczych, która odbyła się w Monachium w 1965 roku. Jej efektem było wydanie monumentalnego dzieła na temat osad zaginionych w Europie pod redakcją naukową R. Romano i P. Courbin. Ważne znaczenie miały zawarte w niej ustalenia na temat zaniku osadnictwa autorstwa badaczy francuskich. Warto podkreślić, że uwidoczniły się tam wyraźne różnice w postrzeganiu zakresu terminologicznego i metod postępowania badawczego w odniesieniu do pustek osadniczych, które wyraźnie różnicują podejścia stosowane przez geografów, historyków i archeologów, co odnajduje swój wyraz m.in. pracach G. Duby (1965) i M. Roncayolo (1965). Należy wskazać także na znaczną wagę podjętych wówczas rozważań natury teoretycznej i metodologicznej. Ciekawie w tym kontekście prezentują się prace na temat potencjalnej bazy źródłowej i możliwości jej wykorzystania, czego przykładem jest studium na temat pisanych źródeł historycznych autorstwa J.M. Pesez (1965) oraz zdjęć lotniczych autorstwa R. Chevalliera (1965). Syntetyczne opracowanie z 1965 roku uwzględnia także próby zaprezentowania przeglądu badań i cząstkowych raportów z wyników studiów poświęconych osadom zaginionym w różnych częściach Europy. Adekwatnymi przykładami są w tym przypadku prace na temat osad zaginionych 
w południowej Europie N. Cabrillana (1965) dla Hiszpanii, C. Klapisch-Zuber i J. Day (1965) dla Włoch, H. Antoniadis-Bibicou (1965) dla Grecji oraz osad zaginionych w północnej Europie H. Bjørkvika (1965) w Szwecji i T. Ramskou (1965) w Danii. Studia te uwzględniają lokalną specyfikę procesów osadniczych oraz poligenetyczne uwarunkowania powstawania pustek. Warto w tym kontekście wskazać także krótki artykuł autorstwa historyka A. Gieysztora (1965), który dokonał bilansu badań na ten temat w Polsce, wskazując na interdyscyplinarne ujęcia tematu, uwzględniając różne etapy procesów feudalizacji i kryzysów agrarnych. Pokłosiem omawianej konferencji było wzmożenie aktywności naukowej, czego efektem było wydanie pracy kompleksowo traktującej o osadach zaginionych we Francji autorstwa J.M. Pesez i E. Le Roy Ladurie (1965) oraz studium metodologicznego pióra P. Courbin (1965). Dużą rolę przypisać można sformułowanym przez niego wytycznym, biorących pod uwagę szeroki zakres przyczyn powstawania pustek, w tym szereg determinant przyrodniczych, politycznych i gospodarczych skutkujących depopulacją i trwałym zanikiem zagospodarowania. Dyskusja o zasięgu europejskim na temat osad zaginionych odnalazła swe odbicie także w syntetycznych ujęciach relacjonowanych przez J. Peltre'a (1966) czy P. Ponsot (1968).

Równolegle prowadzone były także badania na ten temat w Wielkiej Brytanii. Przełomowe w tym zakresie wydają się prace M.W. Beresforda (1951, 1954), który jako pierwszy dokonał próby omówienia zjawiska zaniku osadnictwa zarówno w ujęciu teoretycznym, jak i metodologicznym. Przede wszystkim zaproponował na szeroką skalę konfrontację ustaleń historycznych z wynikami badań archeologicznych, w tym analiz nieinwazyjnych. W tym kontekście stał się pionierem wykorzystania na szeroką skalę zdjęć lotniczych w procesie badawczym identyfikacji i lokalizacji opustoszałych osad, które badał od okresu wczesnego średniowiecza (inwazji normandzkiej) aż po grodzenie pól w początkowej fazie epoki nowożytnej. Badania zainicjowane przez M. Beresforda zyskały licznych kontynuatorów, którzy rozszerzyli wyraźnie zakres analiz, czego efektem były kompleksowe prace K.J. Allison (1970), R. Muir (1982), L. Driver (2006) oraz C. Dyera i R. Jonesa (2010). Zagadnienie osad zaginionych cieszy się ogromnym zainteresowaniem różnych środowisk naukowych, podejmujących wzmożoną współpracę, czego doskonałym przykładem jest działalność interdyscyplinarnej grupy badawczej Deserted Medieval Village Research Group. Na podstawie wypracowanych rozwiązań metodycznych ukazało się wiele prac o charakterze regionalnym, czego przykładem może być studium M.W. Beresforda (1954) na temat regionu Yorkshire, K.J. Allison, M.W. Beresforda i J.G. Hurst $(1965,1966)$ dla Oxfordshire i Northamptonshire, K. Rutherford-Davisa (1973) dla Hertfordshire, G.R. Burleigh (1973) i J. Vigar (1994) dla Sussex, J. Hall i A. Hamlin (1976) dla Devon, C. Dyer (1982) dla West Midlands, A. Davison (1996) dla Norfolk czy S. Oosthuizen (2009) dla Cambridgeshire. 
Badania zachodnioeuropejskie stały się inspiracją dla podejmowania analogicznych studiów nad zaginionym osadnictwem w Europie Środkowej. Szczególnie długą tradycję w tym zakresie wykazuje historiografia czeska, której dokonania były niekiedy wzorcem dla podstaw teoretycznych oraz rozwiązań metodycznych w tym zakresie dla polskich badań geograficzno-historycznych i archeologicznych osadnictwa. Warto w tym kontekście wskazać przełomową pod względem empirycznym pracę V. Nekuda (1975), zwiastującą cykl prac na temat osad zaginionych. Kluczowe znaczenie wykazują przede wszystkim metodyczne prace E. Černý $(1979,1992)$, stanowiące wzorzec dla niektórych badaczy polskich podejmujących omawianą problematykę. Autor ten zaproponował dwa etapy postępowania badawczego. Pierwszy z nich ma charakter wstępny i polega na kwerendzie źródeł historycznych, zebraniu danych toponomastycznych i materiałów kartograficznych. Ich analiza umożliwia identyfikację przypadków zaginięcia osad oraz przeprowadza próbę ich przybliżonej lokalizacji, opierając się na wskazówkach pochodzących z materiału źródłowego, kierując się przynależnością terytorialną, lokalnym nazewnictwem, sąsiedztwem obiektów fizjograficznych czy przebiegiem dawnych dróg. Kolejny etap postępowania wykazuje już charakter rozpoznawczy i polega na weryfikacji terenowej, w formie badań powierzchniowych w celu identyfikacji i interpretacji znalezisk (np. pozostałości budownictwa, ceramiki, śladów orki), które uznać można za relikty zanikłych osad.

\section{Zagadnienie osad zaginionych w świetle geohistoriografii polskiej}

Jak wcześniej wspomniano, badania nad zagadnieniem pustek osadniczych w Polsce, ze szczególnym uwzględnieniem tzw. osad zaginionych, nie doczekały się, w porównaniu z nauką zachodnioeuropejską, zbyt bogatego dorobku. Problem częściowego lub całkowitego zaniku osadnictwa był do tej pory marginalizowany w polskich badaniach geograficzno-historycznych. W nikłym stopniu prowadzono kompleksowe badania dotyczące zaniku osad w szerszej skali przestrzennej w aspekcie wykorzystania źródeł historycznych, w tym kartograficznych i zdjęć lotniczych, w powiązaniu z wynikami badań archeologicznych. Rzadko badania te prowadzone były zespołowo i w związku z tym nie podlegały interdyscyplinarnej konfrontacji. Omawiana kwestia stanowiła najczęściej przedmiot rozważań w kontekście szerszych analiz poświęconych rozwojowi osadnictwa w różnych skalach czasowych i o różnym zasięgu terytorialnym. Najlepszym tego przykładem są opracowania atlasowe w ramach realizacji serii Atlasu Historycznego Polski w II połowie XVI wieku czy słownikach historyczno-geograficznych w średniowieczu sporządzanych sukcesywnie dla poszczególnych regionów administracyjnych z okresu staropolskiego (zob. szerzej: Pałucki 1967; Górska-Gołaska 2003). Przełomowym opracowaniem traktującym wąsko specjalistycznie na temat pustek osadniczych na gruncie polskiej geohistoriografii była praca S. Miel- 
czarskiego i J.R. Szaflika (1956). Autorzy w dość wąski sposób ujęli zagadnienie łanów pustych, ograniczając badania wyłącznie do łanów chłopskich, pomijając w swych rozważaniach inne formy własnościowe gruntów oraz opustoszenia zagród i pozostałych struktur osadniczych. Zawężono także zakres chronologiczny rozważań od XIV do połowy XVII wieku, argumentując to dostępnością źródeł dokumentowych, co w oczywisty sposób pomija archeologiczne dowody zaniku osadnictwa. Autorzy zaprezentowali bazę źródłową oraz skupili uwagę na aspekcie genezy i uwarunkowań społeczno-gospodarczych pustek w kontekście ich lokalizacji. Brak jest natomiast jednoznacznego zdefiniowania czy klasyfikacji. Pierwsze próby w tym zakresie odnaleźć można dopiero w opracowaniu W. Rusińskiego (1961). Badacz ten na potrzeby swego opracowania wskazał, że pustki osadnicze odnoszą się do obszarów początkowo zasiedlonych, a następnie opuszczonych i nieużytkowanych gospodarczo na stałe lub w dłuższej perspektywie czasowej. Zwraca jednak uwagę, że w wielu przypadkach granice pomiędzy ugorem a odłogiem są dość płynne w świetle materiału źródłowego. Nie uwzględnia on w swych rozważaniach, choć wyraźnie rozróżnia, osiedla odnotowane jako opustoszałe, których ziemie zostały wzięte w użytkowanie przez mieszkańców osad sąsiednich, np. na drodze konsolidacji lub inkorporacji, co określa mianem pustek pozornych.

W kontekście omawianej problematyki za niezwykle istotne uznać należy ponadto dokonania naukowe S. Wojciechowskiego (1930). Dotyczyły one kwestii osad zaginionych na obszarze Lubelszczyzny, a zainicjowane zostały w okresie międzywojennym pod kierunkiem W. Semkowicza. Po II wojnie światowej i wydaniu w 1966 roku mapy województwa lubelskiego w ramach serii Atlasu Historycznego Polski, kwerendę podjęto ponownie, czego efektem było wydanie kompleksowego studium na temat zaniku osadnictwa na omawianym obszarze, rozumianego w kategoriach zupełnych zaginięć, a nie tylko częściowych opustoszeń (Wojciechowski i in. 1986). W formie słownikowej zestawiono osady zaginione, istniejące w przeszłości, a dzisiaj już nie notowane. Uwzględniono także osady wchłonięte przez osiedla sąsiednie, których nazwy obecnie funkcjonują jako nazwy części wsi i miast lub w ogóle zaniknęły. Ujęto również osady, których nazwy uległy zmianom na przestrzeni dziejów, co odnotowały źródła pisane od XII do XX wieku. Zakres merytoryczny opracowania prezentuje zatem poglądy autora na postrzeganie tzw. osad zaginionych. Nie uwzględnia on np. osad zaginionych okresowo, które po dłuższym okresie niebytu, przechodziły często proces relokacji. Badaniom podlegały natomiast zaginięcia pozorne, $\mathrm{w}$ ramach których mamy do czynienia z zanikiem determinowanym np. rozwojem terytorialnym niektórych osiedli (głównie miast) kosztem sąsiednich wsi. W słowniku znalazły się łącznie 732 osady, w tym 283 osady zaginione (w tym 178 opustoszałych i 105 włączonych do innych osiedli). Zostało także uwzględnionych 449 osad o nazwach zmienionych. 
Inne spojrzenie na omawianą kwestię prezentuje E. Rymar (1971) w swoim studium poświęconym zanikowi osadnictwa na obszarze powiatu pyrzyckiego. Wśród zanalizowanych 32 przypadków (w tym dawnych grodów) wskazał on wyłącznie na obszary pierwotnie zasiedlone, podlegające zabudowie, które po opustoszeniu z przyczyn przyrodniczych, politycznych czy gospodarczych są nadal możliwe do identyfikacji terenowej dzięki reliktom archeologicznym i tzw. nazwom polnym. Jest to przykład szczególnego rozumienia problemu, dość wąsko traktującego zakres badanych osad. Autor stawia ponadto prymat badań archeologicznych, wskazując niekiedy na bezimienne osady, które zaginęły jeszcze we wczesnym średniowieczu, w okresie poprzedzającym ich pierwsze zapisy źródłowe. Niewątpliwie poglądy te pozostały pod silnym wpływem metodologii badań osadnictwa średniowiecznego, których propagatorem był przede wszystkim W. Hensel (1960), jeden z twórców wytycznych postępowania badawczego w zakresie omawianej problematyki. Jak widać, zagadnienie osad zaginionych różnie postrzegane było przez poszczególnych badaczy, którzy swe rozważania koncentrowali na kwestii zaniku osadnictwa w okresie średniowiecza. Można wskazać jedynie nieliczne opracowania podejmujące wskazany problem w stosunku do osadnictwa nowszego pochodzenia. Szczególnym zainteresowaniem polskich badaczy w ostatnich latach cieszy się natomiast problem powstawania osad zaginionych w wyniku oddziaływania czynników politycznych w XX wieku, czego przykładami mogą być analizy opustoszałych wsi Rusinów karpackich autorstwa S. Kłosa (2010), J. Wolskiego (2007) w Bieszczadach czy A. Piecucha $i$ in. (2013) dla ziemi gorlickiej. Podejmowano także badania w odniesieniu do osad zaginionych w Sudetach (m.in. Szmytkie 2008; Latocha 2013). W analizowanych przypadkach wciąż dostrzegalne są ślady dawnego zagospodarowania w krajobrazie kulturowym, choć badane osady spełniają kryterium całkowitego wyludnienia. Istnieje oczywiście wiele innych opracowań historycznych i archeologicznych, w których na marginesie eksplikacji procesu rozwoju osadnictwa zostało uwzględnione w minimalnym stopniu zjawisko pustoszenia osad. Odnoszą się jednak one do pojedynczych punktów osadniczych lub dotyczą wąskiej skali regionalnej jako jeden $\mathrm{z}$ wielu wątków ujmowanych w szerszym kontekście badawczym. W związku z powyższym zostały one pominięte w niniejszych rozważaniach, gdyż zawarte w nich jednostkowe dane faktograficzne niewiele wnoszą do dyskusji teoretyczno-metodologicznej w zakresie omawianej problematyki.

\section{Próba uściślenia pojęć i reklasyfikacji}

Z powyższych rozważań wyraźnie wynika, że na gruncie polskim panuje znaczny chaos oraz brak jednoznaczności i konsekwencji w zakresie stosowanych pojęć. W literaturze przedmiotu pojawia się wiele desygnatów odnoszących się pustek całkowitych w postaci osad zanikłych, zaginionych, zagubionych, 
opuszczonych czy opustoszałych o niejasnym zakresie znaczeniowym. Wiele z podanych pojęć wykazuje zbyt szeroki, inne zbyt wąski sposób postrzegania, różnie interpretowany $\mathrm{w}$ poszczególnych opracowaniach. W literaturze bazującej na odmiennych koncepcjach i wzorcach metodologicznych pojawiło się wiele nieścisłości terminologicznych i klasyfikacyjnych, które wymagają uporządkowania i systematyzacji. W świetle krytycznej analizy piśmiennictwa oraz zgromadzonego materiału źródłowego istnieje jednak możliwość doprecyzowania aparatu pojęciowego. W przekonaniu autora niniejszego artykułu pojęciem nadrzędnym w stosunku do problemu zaniku osadnictwa jest niewątpliwie pustka osadnicza. W kontekście referowanego wcześniej obcego i częściowo rodzimego piśmiennictwa jawi się ona jako obszar ekumeny, która ze względu na zróżnicowane uwarunkowania przyrodnicze, polityczne i gospodarcze przestała być trwale zasiedlona i nie podlegała już gospodarczemu wykorzystaniu w stopniu częściowym lub zupełnym. W zaproponowanym rozumieniu tego terminu kryją się zatem wszelkie przypadki zaniku osadnictwa, zróżnicowanego pod względem morfologicznym, które w dłuższej perspektywie czasowej przestały być zagospodarowane, począwszy od pojedynczego łanu po całe osady. Zjawisko powstawania pustek osadniczych w rozumieniu częściowym było i jest powszechne w warunkach kurczenia się wielu miast i wsi. Jest też dobrze uchwytne w świetle dostępnego materiału źródłowego. Dla przykładu, według sumarycznych ustaleń z początku XVI wieku, łany puste mogły stanowić okresowo nawet $1 / 3$ wszystkich nadziałów gruntowych. Na podstawie badań J. Warężaka (1929) można stwierdzić, że w dobrach arcybiskupstwa gnieźnieńskiego w 1512 roku w 297 wsiach zidentyfikowano 3797 łanów osiadłych i 1369 łanów pustych, co stanowi 26,51\% ogólnej liczby łanów kmiecych. Według obliczeń S. Inglota (1927) w odniesieniu do dóbr biskupstwa włocławskiego w roku 1534 w 176 wsiach było 1081 łanów osiadłych, a 730 łanów pustych, czyli 40,31\% ogólnej liczby. Podobny lub nieco lepszy stan notuje się również w królewszczyznach, na co wskazywać może analiza wielu inwentarzy dóbr monarszych w tym czasie (Bujak 1908).

W świetle dotychczasowych rozważań osadę zaginioną potraktować można zatem jako szczególny przypadek pustki osadniczej, która spełnia kryterium zupełnego zaniku i odnosi się do całości jednostki osadniczej (zarówno zabudowy jak i rozłogów). Osada zaginiona ex definitione winna bowiem wskazywać na zaistnienie faktu całkowitego opuszczenia. Należy przy tym wyraźnie stwierdzić, że osada zaginiona jest pojęciem wykazującym szeroki zakres semantyczny. W ujęciu zaproponowanym przez autora osada zaginiona sensu largo to osada, która na pewnym etapie swego funkcjonowania została całkowicie opuszczona $\mathrm{i} /$ lub jej nazwa jako samodzielnej jednostki osadniczej zaginęła w świetle dostępnego materiału źródłowego. Jest to niewątpliwie najszersze rozumienie omawianego pojęcia, obejmującego zarówno zjawisko faktycznego opustoszenia, jak i przypadki pozornego zaniku osadnictwa. W tym kontekście istnieje możliwość 
dokonania klasyfikacji obejmującej dwie kategorie. Pierwsza z nich tworzy osady zaginione sensu stricto. Są to inaczej osady zaginione w sposób rzeczywisty (de facto), w których doszło do całkowitego przerwania ciągłości osadniczej, czyli opustoszenia wskutek ekstremalnych zjawisk przyrodniczych, reperkusji wojen i klęsk elementarnych oraz szeroko rozumianych przemian struktury gospodarczej. Druga kategoria w zaproponowanym ujęciu teoretycznym obejmuje osady zaginione pozornie (de iure). Są to osady zanikłe w sensie toponimicznym w materiale źródłowym w wyniku prawno-administracyjnych procesów konsolidacji osad już istniejących, inkorporacji do pobliskich miejscowości lub zjawiska denominacji (zmiany nazwy własnej).

\section{Typy osad zaginionych pozornie (de iure)}

Przyjrzyjmy się zatem nieco bliżej ostatniej z omawianych kategorii osad zaginionych. Jedną z okoliczności, w których mamy do czynienia z pozornym zanikiem osadnictwa jest przypadek zaprzestania stosowania określonej nazwy własnej jednostki osadniczej w dostępnym materiale historycznym. Brak obecności danej nazwy w źródłach późniejszych chronologicznie może w pierwszej kolejności sugerować sytuację, w której badana osada przestała istnieć. Szczegółowa analiza zapisów źródłowych w wielu sytuacjach daje jednakże podstawę, by dokonać identyfikacji zamiany jednej nazwy na inną w stosunku do tej samej jednostki osadniczej. Dla przykładu z badań własnych autora wynika, że wieś Mogilno, zlokalizowana obecnie na obszarze powiatu pabianickiego nosiła niegdyś nazwy Latalice i Wola Latalska. Otóż lokacji wsi in cruda radice noszącej pierwotnie nazwę Latalice dokonał ok. 1513 roku ówczesny tenutariusz dóbr pabianickich kapituły krakowskiej Jan Latalski. Wieś powstała na skutek akcji osadniczej na terenie pokarczunkowym ${ }^{1}$. W rejestrach poborowych z lat 1552-1553 odnajdujemy informację o liczbie łanów kmiecych w Woli Latalskiej². Doszło zatem do zmiany nazwy, która zapewne podkreślać miała wolniznę nowo lokowanej osady. W aktach wizytacyjnych z 1577 roku odnajdujemy wzmiankę o łanach oraz wysokości świadczeń feudalnych w Mogilnie ${ }^{3}$. Na podstawie danych o lokalizacji wsi oraz późniejszych przekazów źródłowych można stwierdzić, że mamy do czynienia $\mathrm{z}$ tą samą miejscowością. Inny podobny przypadek dotyczy wsi Ostre lokowanej in cruda radice przez tenutariusza dóbr królewskich, łowczego łęczyckiego Stanisława z Pełczysk w 1425 roku w lasach

${ }^{1}$ Księga wizyt dóbr Pabianice należących do uposażenia kapituly krakowskiej 14961540, Wyd. B. Ulanowski, Kraków 1921.

${ }^{2}$ Polska XVI wieku pod względem geograficzno-statystycznym opisana przez Adolfa Pawińskiego, t. 2: Wielkopolska, [w:] Źródła Dziejowe, t. 13, Warszawa 1883, s. 238.

${ }^{3}$ Archiwum Krakowskiej Kapituły Katedralnej, księgi rachunków rocznych dotyczących dóbr pabianickich Kapituły krakowskiej z 1577 roku, za: Nowak, Adamek 2000. 
należących do wsi Ostrówki ${ }^{4}$. Na podstawie rejestrów poborowych z połowy XVI wieku pozyskujemy informację o liczbie łanów we wsi Ostra alias Copy ${ }^{5}$. W lustracji królewszczyzn z 1564 roku zawarte są już wyłącznie dane na temat wsi o nazwie Kopy ${ }^{6}$. Ewidentnym przypadkiem zaniku dawnej nazwy są chociażby zmiany wymuszone administracyjnie w zakresie wsi związanych z kolonizacją fryderycjańską, zakładanych na obszarach rdzennie polskich, np. w Prusach Południowych w latach 1793-1807. Nazwy tych wsi miały niemieckojęzyczny charakter, nawiązujący bardzo często do miejsca pochodzenia osadników (Figlus 2013; Woźniak 2013). Postanowieniem namiestnika Królestwa Polskiego z 2 maja 1820 roku uległy one spolszczeniu (Heike 1979, s. 61). Niekiedy korespondowały ze sobą znaczeniowo (np. wieś Grünberg przemianowana została na Zieloną Górę, a Engelhardt na Aniołów). Zazwyczaj mamy jednak do czynienia z zupełnie odmienną nazwą, nienawiązującą leksykalnie do oryginalnej (np. Groembach to współczesna Łaznowska Wola, a Hochweiler stała się wsią Markówka). W każdym przypadku jest to jednak ta sama osada, a zmiany miały charakter wyłącznie prawno-administracyjny. Reasumując, należy zachować ostrożność w analizie materiału źródłowego, gdyż miejscowość pochopnie uznana za zaginioną, mogła dalej funkcjonować, lecz pod zmienioną nazwą własną.

Nie są także odosobnione przypadki procesów osadniczych, w których mamy do czynienia z zanikiem nazwy osady wskutek konsolidacji sąsiadujących ze sobą wsi. Dotyczy to w szczególności obszarów z dominacją tzw. szlachty cząstkowej i zagrodowej. Dochodziło w nich bowiem, w wyniku umów posagowo-wiennych i spadkowych, do wielokrotnych podziałów macierzystych osad, co określa się niekiedy mianem pączkowania na płaszczyźnie osadniczej. Z czasem nazwy nowych wsi lub ich człony zanikały wraz z procesem komasacyjnym. Egzemplifikacją tego może być wieś Żakowice, odnotowana po raz pierwszy w 1386 roku $^{7} \mathrm{Na}$ skutek podziałów majątkowych, w drugiej połowie XV wieku powstało osiedle o nazwie Żakowice Wielkie, Żakowice Małe i Żakowice-Puśniki ${ }^{8}$. Według rejestru poborowego z 1576 roku funkcjonowała jeszcze osada Gose (od właściciela Jana Żakowskiego vel Gosz), a Puśniki zostały włączone do Żakowic Małych ${ }^{9}$. Mapy z początku XIX wieku identyfikują już tylko dwie osady: Żakowice

${ }^{4}$ Matricularum Regni Poloniae summaria, t. 1, Wyd. T. Wierzbowski, Warszawa 1905, nr 1515.

${ }^{5}$ Polska XVI wieku..., op. cit., s. 50.

${ }^{6}$ Lustracja województw wielkopolskich i kujawskich 1564-1565, cz. 2, Wyd. A. Tomczak, Bydgoszcz 1963, s. 179.

${ }^{7}$ Księgi sądowe łęczyckie od 1385 do 1419, cz. 1, [w:] Teki A. Pawińskiego, t. 3, Warszawa 1897, $\mathrm{nr} 72$.

${ }^{8}$ Jana Łaskiego Liber beneficiorum archidyecezyi gnieźnieńskiej, t. 2, Wyd. J. Łukowski, Gniezno 1881, s. 483.

${ }^{9}$ Polska XVI wieku..., op. cit., s. 238. 
(dawne Wielkie) oraz Puśniki (dawne Małe). Efemeryczna Gose stała się więc w międzyczasie częścią jednej z nich ${ }^{10}$. Udokumentowanych źródłowo przykładów tego typu wskazać można oczywiście niezwykle dużo (zob. Figlus 2011).

Innym typem pozornego zaginięcia jest inkorporacja do osady sąsiedniej. Szczególnie dużo przypadków tego typu odnaleźć można w kontekście rozwoju terytorialnego wielu miast polskich. Relikty dawnych osad funkcjonujących niegdyś jako autonomiczne punkty osadnicze są jednak wyraźnie zróżnicowane w krajobrazie kulturowym. Wystarczy porównać ze sobą dwa przykłady dawnych wsi włączonych do granic administracyjnych Łodzi: Mileszki oraz Żabieniec (Stępniewski, Szambelan 2009). Pierwsza wzmianka na temat Mileszek pochodzi z 1393 roku i odnosi się do zapisek sądu ziemskiego, choć przypuszczać można, że metryka historyczna wsi jest znacznie wcześniejsza ${ }^{11}$. Wieś po kilkuset latach nieprzerwanego istnienia straciła swój dotychczasowy status w 1988 roku $\mathrm{w}$ wyniku zmian granic Łodzi ${ }^{12}$. Jej dawny układ przestrzenny w postaci owalnicy z dobrze zachowanymi pozostałościami niwowego układu gruntowego pozostaje nadal w pełni czytelny. Żabieniec jest przykładem wsi nowożytnej związanej z osadnictwem olęderskim. Została założona na obszarze pokarczunkowym w 1793 roku przez właściciela pobliskiego Radogoszcza Mateusza Strzałkowskiego i początkowo nazywana była Holendrami Radogoskimi (Kossmann 1942, s. 160-163, por. Goldberg 1957, s. 88). Wieś zaniknęla jako samodzielna jednostka osadnicza w 1915 roku na skutek inkorporacji do Łodzi ${ }^{13}$. W wyniku procesów intensywnej urbanizacji i industrializacji układ dawnego Żabieńca uległ całkowitej transformacji, a jedynym śladem nieistniejącej już osady w przestrzeni są relikty cmentarza ewangelickiego przy ul. Brukowej. Na stan zachowania zanikłych wsi wpływ miały zatem zarówno okres inkorporacji, jak również zakres przekształceń morfologicznych. W obu omawianych przypadkach zachowały się natomiast nazwy jednostek administracyjnych funkcjonujących w mieście (np. osiedli lub ulic), wskazujących na lokalizację inkorporowanych osad.

Co ciekawe, można również wskazać przypadki zaginięcia de iure miast w wyniku inkorporacji, czego przykładem może być chociażby Łąkoszyn. Pierwsza wzmianka źródłowa na jego temat pochodzi z 1359 roku, znana z późniejszej zapiski z XVI wieku, dotyczącej ustalenia przez arcybiskupa Jarosława Bogorię

${ }^{10}$ Special Karte von Südpreussen, D. Gilly, Berlin 1802-1803, 1:150 000, BUŁ, sygn. K 159.

${ }^{11}$ Księgi sadowe tęczyckie..., op. cit., nr 2825.

${ }^{12}$ Uchwata Rady Narodowej Miasta Łodzi nr XXVH/161/87 z dnia 29 czerwca 1987 roku w sprawie zmiany granic miasta Łodzi, M.P. nr 25, poz. 205, z dnia 4 września 1987 roku.

${ }^{13}$ Obwieszczenie Wojewody Łódzkiego z dnia 11 maja 1935 roku o stwierdzeniu i ustaleniu granic miasta Łodzi, Łódzki Dziennik Wojewódzki nr 10, 1935, poz. 151; Archiwum Państwowe w Łodzi, Zbiór kartograficzny, Mapa rozwoju terytorialnego Łodzi w latach 1821-1915, opracowana w Oddziale Pomiarów Magistratu m. Łodzi, sygn. 2917. 
Skotnickiego zasięgu przestrzennego tutejszej parafii ${ }^{14}$. Osada uzyskała prawa miejskie z inicjatywy prywatnych właścicieli przed 1417 rokiem, na co wskazuje informacja odnosząca się do majątkowego sporu sądowego (Nowak 2011). Rozwijający się sukcesywnie Łąkoszyn nie wytrzymał jednak rywalizacji z położonym po drugiej stronie Ochni Kutnem i z czasem podupadł, tracąc ostatecznie status miasta w niejasnych okolicznościach pod koniec XVIII wieku. Od tego czasu miejscowość odnotowywana była jako wieś aż do 1929 roku, kiedy to została włączona do granic administracyjnych Kutna ${ }^{15}$. Współcześnie Łąkoszyn nie tworzy żadnej jednostki pomocniczej miasta. Znana jest wyłącznie ulica o tej nazwie.

W analizie osad inkorporowanych należy jednak zachować szczególną ostrożność w interpretacji materiału źródłowego, by pochopnie nie dokonać nieuprawnionej klasyfikacji danej osady do grupy zaginionych pozornie (de iure). Warto w tym kontekście jako przykład wskazać wieś Porowcze, będącą niegdyś w posiadaniu kapituły gnieźnieńskiej. W świetle wizytacji dóbr kościelnych z 1534 roku pozyskujemy informację, że wieś ta jako już opustoszała została włączona do sąsiedniego Czerlejno: „Villa deserta incorporata Minori Czerlyenyno, eget novis finium metis cum Clony" ${ }^{16}$. W tej sytuacji inkorporację poprzedziło zatem opustoszenie, a więc zaginięcie o charakterze rzeczywistym, a niezagospodarowane łany zaginionej osady powiększyły następnie areał wsi Czerlejno.

\section{Osady zaginione sensu stricto (opuszczone) - problem chronologii oraz sukcesji osadniczej}

Przejdźmy teraz do rozważań metodyczno-empirycznych odnoszących się do osad zaginionych sensu stricto, tj. zgodnie z zaproponowanym ujęciem teoretycznym takich, w których doszło do całkowitego przerwania ciągłości osadniczej na skutek opustoszenia. W pierwszej kolejności warto zwrócić uwagę na aspekt metryki historycznej zaginięcia oraz jego długotrwałości. W dotychczasowych badaniach geograficzno-historycznych wyraźnie dominowało rozpatrywanie przypadków zaniku osad o genezie średniowiecznej. Tymczasem warto zaznaczyć, że jest to zjawisko uniwersalne, zachodzące w różnych skalach czasowych. Można wskazać liczne przykłady osiedli pochodzenia nowożytnego, które opustoszały w rozmaitych okolicznościach. Wśród nich wyraźnie dominują niewielkie przysiółki, które w sensie funkcjonalnym miały charakter osad młyńskich, karczmarskich czy protoprzemysłowych. W grupie tej należy wymienić liczne huty, rudy, budy czy smolarnie, których funkcjonowanie ukierunkowane było

${ }^{14}$ Jana Łaskiego Liber beneficiorum..., op. cit., s. 481.

${ }^{15}$ Rozporzadzenie Rady Ministrów z dnia 4 lipca 1929 roku o zmianie granic miasta Kutna, w powiecie kutnowskim, województwie warszawskim, Dz.U., 1929, nr 52, poz. 421.

${ }^{16}$ Visitationes bonorum archiepiscopatus necnon capituli Gnesnensis saeculi XVI, Wyd. B. Ulanowski, Kraków 1920, s. 550. 
doraźnie na eksploatację terenów puszczańskich, a wraz z ich stopniowym zanikiem rychło kończyły swój żywot jako samodzielne punkty osadnicze. Ze względu na specyfikę tych osad bardzo często wiele spośród nich jest trudno uchwytnych w świetle dostępnej bazy źródłowej. Efemeryczny charakter wykazują także liczne osady postfolwarczne. W wyniku przebiegającej nierzadko chaotycznej akcji parcelacyjnej dochodziło do powstawania małych kolonii, często kilkuzagrodowych, które z czasem ulegały konsolidacji, tworząc odizolowane, peryferyjne fragmenty większych wsi. Pustoszenie osad obecne jest także we współczesnym krajobrazie kulturowym, co wpisane jest w proces kurczenia wielu miast i wsi. Niekiedy dochodzi jednak do całkowitej depopulacji wywołanej czynnikami politycznymi lub gospodarczymi. Niewątpliwie można w tym kontekście wymienić bardzo liczne wsie w południowo-wschodniej Polsce, zamieszkiwane pierwotnie przez ludność ukraińską, łemkowską czy bojkowską (np. Tyskowa, Ruskie, Choceń, Tworylne). Osady te w wyniku zmian granic po II wojnie światowej i realizacji akcji „Wisła”, skierowanej na zmiany strukturalne ludności poprzez przymusowe migracje, nagle uległy całkowitemu wyludnieniu (Kłos 2010). Obecnie można jedynie odnaleźć w tych miejscach zrujnowane pozostałości chat, zarastające piwnice i fundamenty oraz relikty cmentarzy. Czasami za współczesnym zanikiem osady stoją również determinanty gospodarcze, czego przykładem mogą być wsie zlikwidowane w wyniku realizacji wielkich inwestycji przemysłowych czy infrastrukturalnych. W ten sposób w ostatnim półwieczu w Polsce zniknęło wiele wsi podczas prac eksploatacyjnych, budowie autostrad czy tworzeniu zbiorników zaporowych. Świetnym przykładem w tym zakresie może być Łęg Popowski, który przestał istnieć w związku z budową zbiornika retencyjnego Jeziorsko na Warcie w 1986 roku (Głuszak 1986).

Niezwykle istotny wydaje się także problem długotrwałości zaniku osadnictwa. W materiale źródłowym często możemy odnaleźć wzmianki na temat osad zaginionych, zgodnie z którymi „,villa deserta ab antiquo" lub ,per multos annos”. Te znamienne określenia podkreślają fakt opustoszenia wsi w dłuższej perspektywie czasowej. W wielu przypadkach pojawiają się zapiski wskazujące, że niezasiedlona osada całkowicie porosła lasem, co wskazywać może na co najmniej kilkudziesięcioletni okres wyludnienia i braku zagospodarowania rolniczego. Niech przykładem będzie wieś Zalasowo, w parafii Słomowo odnotowywana jako „villa deserta a multis anni et silve sufficientes" ${ }^{\prime 17}$. Znaczna część z omawianych osad nigdy się nie odrodziła. Warto jednakże podkreślić, że wiele zaginionych wsi, po krótszym lub dłuższym okresie niebytu, podlegała relokacji. Dla przykładu na ogólną liczbę 176 wsi uznanych w Liber beneficiorum Jana Łaskiego za opustoszałe, aż 107 znanych jest współcześnie, co wskazuje na powszechność stosowania powtórnych lokacji (Szaflik 1952, s. 176). W omawianych przypadkach

${ }^{17}$ Liber beneficiorum dioecesis posnaniensis anni 1510, Wydawnictwa źródłowe Komisji Historycznej PTPN, 10, Wyd. J. Nowacki, Poznań 1950, s. 95. 
mamy zatem do czynienia z osadami opuszczonymi okresowo, gdyż spełniają warunek nieciągłości osadniczej na płaszczyźnie demograficznej i czasowego braku zagospodarowania. Jeden z pierwszych przekazów źródłowych na ten temat pochodzi z 1303 roku i odnosi się do należącej do zakonu templariuszy Wielkiej Wsi, która była opuszczona i jako „consistentia meliorari et locari”, została ponownie lokowana na prawie niemieckim ${ }^{18}$. Podobnych informacji późniejszych chronologicznie dotyczących relokacji odnaleźć można znacznie więcej. W wyniku reperkusji zniszczeń wojennych liczba opustoszałych wsi stale rosła, czego przykładem mogą być dobra kapituły warmińskiej podczas wojen polsko-krzyżackich. Część z nich udało się w późniejszym czasie restytuować. W tym kontekście dysponujemy bezcennym źródłem historycznym prezentującym działalność Mikołaja Kopernika na polu procesu relokacyjnego (Locationes mansorum desertorum). Wśród ok. 40 osad odnowionych przez niego wymienić można chociażby przypadek wsi Linowo w powiecie szczanieckim. Została ona założona w 1387 roku na prawie chełmińskim dzięki decyzji wielkiego mistrza Konrada Zollner von Rotensteina. Podczas wojny trzynastoletniej Linowo zostało doszczętnie zniszczone (Grabowski 2006, s. 3-6). Opustoszałą wieś z sukcesem lokował ponownie w 1517 roku Mikołaj Kopernik jako administrator dóbr kapituły warmińskiej ${ }^{19}$.

W świetle zgromadzonego materiału istnieje możliwość sformułowania wniosków na temat sukcesji osadniczej terenów podlegających uprzednio całkowitej depopulacji. Otóż w ujęciu zaproponowanym przez autora, następstwem czasowym całkowitego zaniku osadnictwa na danym obszarze może być wtórne zasiedlenie, dla którego immanentną cechą jest nieciągłość chronologiczna w odniesieniu do osadnictwa wcześniejszego pochodzenia. Sukcesji tej towarzyszy zachowanie całkowitej lub częściowej zbieżności lokalizacyjnej wtórnego osadnictwa w stosunku do pierwotnego, przy możliwości zaistnienia zgodności lub rozbieżności toponimicznej. Bardzo często bowiem po okresie zaniku osadnictwa na danym terenie (w archeologii tzw. hiatus osadniczy), dochodzi do ponownego zasiedlenia, lecz pod zmienioną nazwą własną. Jaskrawym przykładem w tym zakresie jest niewątpliwie sukcesja osadnictwa obejmującego dawną wieś królewską Wiączyń Polny (na terenie współczesnej Łodzi), która odnotowywana jest jeszcze w inwentarzach dóbr monarszych z 1789 roku oraz widoczna jest na planie z 1796 roku $^{20}$, po czym w wyniku decyzji władz pruskich uległa likwidacji, a na jej miejscu utworzona została w 1801 roku w ramach kolonizacji fryderycjańskiej wieś Neu Sulzfeld, znana później jako Nowosolna (Heike 1979;

${ }^{18}$ Kodeks dyplomatyczny Wielkopolski, t. 2, Wyd. I. Zakrzewski, Poznań 1878, s. 217.

${ }^{19}$ Mikołaja Kopernika lokacje łanów opuszczonych, Wyd. Marian Biskup, Olsztyn 1970, s. 98.

${ }^{20}$ Lustracja województw wielkopolskich i kujawskich 1789, cz. 3: Województwa łęczyckie i brzesko-kujawskie, Wyd. A. Tomczak, Z. Kędzierska, Warszawa-Poznań-Toruń 1977, s. 181-183; AGAD, Zbiór Kartograficzny, sygn. 326-17. 
Woźniak 2013). W analizowanym przypadku mamy jednak do czynienia z dwiema zupełnie różnymi osadami, choć o zbieżnej lokalizacji geograficznej, lecz odmiennym rozplanowaniu oraz strukturze społeczno-kulturowej i gospodarczej.

\section{Rekonstrukcja przyczyn przerwania ciąglości osadniczej}

Kolejnym zagadnieniem wartym dyskusji jest niewątpliwie rekonstrukcja przyczyn zaniku osadnictwa. W materiale źródłowym często jednoznaczne ich określenie jest niemożliwe i opiera się w mniejszym lub większym stopniu na hipotezach. Dużo więcej odnaleźć można wzmianek traktujących o opustoszeniu pojedynczych łanów aniżeli wykryć determinanty zaginięcia całych osad. Dla przykładu na ok. 250 osad zaginionych, zidentyfikowanych na obszarze Lubelszczyzny, aż w 131 przypadkach nie udało się w ogóle określić okoliczności zaniku, a w wielu innych wskazane przyczyny opierały się wyłącznie na przypuszczeniach autorów opracowania na ten temat (Wojciechowski i in. 1986, s. 15). W dotychczasowej historiografii osadniczej zaproponowanych zostało wiele koncepcji teoretycznych opierających się na materiale empirycznym, których celem było wyjaśnienie uwarunkowań powstawania pustek, ze szczególnym uwzględnieniem całkowitego zaniku osad. Jedną z bardziej popularnych, zwłaszcza wśród badaczy niemieckich, była teoria propagowana przez W. Abla (1943), zgodnie z którą przyczyn zjawiska szukać należy we fluktuacji procesów ekonomicznych w zależności od koniunktury i panujących systemów ustrojowo-gospodarczych. Wymienić można chociażby zmieniające się warunki gospodarowania w kontekście feudalizacji stosunków społecznych, koncentracji osadnictwa w związku z upowszechnieniem trójpolówki i lokacją na prawie niemieckim. Dla Europy Środkowo-Wschodniej będzie to niewątpliwie rozwój gospodarki folwarczno-pańszczyźnianej, a następnie reformy agrarne związane z uwłaszczeniem chłopów w XIX wieku, dla Europy Zachodniej pokreślić trzeba znaczenie rozwoju stosunków kapitalistycznych oraz usankcjonowanego prawnie zjawiska grodzenia pól (enclosures). Wspomniany badacz sugerował wręcz możliwość wydzielenia okresów powstawania pustek w związku z kumulacją sprzyjających temu czynników (Wüstungsperioden). Okresy te cechują się niestabilnością osadnictwa, która jest wynikiem gwałtowanych zmian w systemie użytkowania ziemi i restrukturyzacją stosunków społecznych. Rzecz jasna, w ujęciu makroskalowym można dowieść znaczenia wskazanych wyżej przyczyn w procesie zaniku osadnictwa, jednakże rytmika procesów gospodarczych jest zazwyczaj niewystarczającą przesłanką w interpretacji faktów jednostkowych w zakresie zaginięcia poszczególnych osad.

Dużą popularność zyskała również wśród wielu badaczy teoria chybionej lokalizacji, zgodnie z którą do zaniku dochodziło często ze względu na niewłaściwe, z przyrodniczego punktu widzenia, położenie osady (zob. Rusiński 1961). Za 
przykład w tym zakresie niech posłuży nieistniejąca współcześnie wieś Mchowo, założona w średniowieczu nad jeziorem Miedwie. Wymieniona została po raz pierwszy w 1316 roku w kontekście opisu granic wsi Turze, sprzedanej wówczas przez Ottona I cystersom kołbackim ${ }^{21}$ (por. Rymar 1971, s. 153). Osada leżała prawdopodobnie zbyt nisko $\mathrm{w}$ obrębie niecki jeziornej i po podniesieniu się lustra wody rychło ulegała zanikowi z uwagi na niekorzystne warunki lokalizacyjne. Do zaniku wielu osad niewątpliwie przyczyniły się także naturalne zmiany środowiska przyrodniczego, związane np. z ruchami masowymi na stoku czy zjawiskiem meandrowania rzek. Egzemplifikację tego stanowić może wieś Orzechów, która zaniknęła zupełnie z uwagi na zmiany koryta rzecznego Wisły, o czym informuje nas zapiska źródłowa z XV wieku: ,villa quondam fuit culta et possessa ... aut desolationem versa esse ... aut fluminis Vistulae alluvione absorpta"22. Ogromne znaczenie w zakresie całkowitego zaniku osadnictwa wykazywały z całą pewnością klęski elementarne. Cenne w tym zakresie wydają się m.in. ustalenia A. Walawendera (1932-35) dla epoki późnośredniowiecznej i wczesnonowożytnej. Pożary, zarazy czy powodzie bardzo często decydowały bezpośrednio o zaniku osadnictwa na danym obszarze. Przykładem katastrofalnego w skutkach pożaru, obejmującego całą wieś, może być uchwytny w źródłach przypadek Stęszewa, będącego w posiadaniu kapituły poznańskiej. Zgodnie z przekazem z 1431 roku wspomniana wieś ,per ignis voraginem sit exusta”23 (por. Szaflik 1952, s. 172). Ofiarą ekstremalnych zjawisk hydrologicznych może być natomiast wieś Młynkowo, należąca niegdyś do biskupa poznańskiego, spustoszona zupełnie przez powódź, o czym informuje wzmianka źródłowa z początku XVI wieku: ,villa in toto desertata per stagnum ibidem"24 (por. Mielczarski i Szaflik 1956, s. 84).

Zasadniczą rolę w zakresie całkowitego opustoszenia osad wykazują ponad wszystko konflikty wojenne. Przyczyniają się one do zniszczenia zabudowy i pól uprawnych oraz śmierci mieszkańców i inwentarza żywego. Wspomnieć należy chociażby o skutkach licznych najazdów tatarskich, litewskich i krzyżackich w średniowieczu oraz efektach osadniczo-gospodarczych wojen północnych z udziałem Szwecji i Rosji czy wojny trzydziestoletniej w odniesieniu do terenów zachodniej Polski. Znamienną w treści jest na przykład relacja angielskiego kupca J. Marshalla, który podróżując wiosną 1670 roku pisał: „Z Rawy do Sieradza obszar ten jak można dostrzec, był kiedyś uprawny, teraz napotkaliśmy tu tylko trzy niezamieszkałe wsie. Pozostałe były doszczętnie spalone, a mieszkańcy uciekli” (Zawadzki 1963, s. 324; zob. też Rusiński 1957; Srogosz 1990). Świetnym

${ }^{21}$ Pommersches Urkundenbuch, Bd. 5, Wyd. O. Heinemann, Stettin 1903, s. 251.

${ }^{22}$ Joannis Dtugosz Liber beneficiorum dioecesis cracoviensis, t. 3, Opera omnia, t. 9, Wyd. L. Łętowski, Kraków 1864, s. 272.

${ }^{23}$ Monumenta Medii Aevi Historica res gestas Poloniae illustrantia, t. 13, Acta capitulorum nec non iudiciorum ecclesiasticorum selecta, Wyd. B. Ulanowski, Kraków 1894, s. 10.

${ }^{24}$ Liber beneficiorum dioecesis posnaniensis..., op. cit., s. 168. 
przykładem jednostkowym może być niewątpliwie wieś Trzebiczna pod Szadkiem (Figlus 2015). Wieś notowana jest w źródłach od 1276 roku $^{25}$. Z 1511 roku odnajdujemy wzmiankę o opustoszeniu części osady - ,parte regalis per totum deserta" ${ }^{26}$. W świetle zaś lustracji królewszczyzn z lat 1659-1665 w Trzebicznej „ostatek pusto gruntów leżało, a teraz zaś wszyscy spustoszeli, żadnego poddanego dla srogich opresyj żołnierskich niemasz"27.

Jak wcześniej wspomniano, w interpretacji opustoszenia osad w czasach bliższych współczesności, przyczyn zjawiska należy doszukiwać się przede wszystkim w sferze reperkusji zmian granic politycznych i sytuacji geopolitycznej oraz w dziedzinie nowych inwestycji gospodarczych i infrastrukturalnych, które determinują częstokroć wymuszone migracje ludności, a co za tym idzie prowadzą do depopulacji terenów do tej pory zasiedlonych. Ciekawym przykładem całkowitego i zarazem okresowego opustoszenia mogą być w ostatnim czasie w Polsce chociażby miejscowości: Kłomino (gm. Borne Sulinowo) czy Pstrąże (gm. Bolesławiec), które wyludniły się zupełnie ze względu na ewakuację miejscowej ludności, którą stanowili żołnierze radzieccy stacjonujący tu w ramach Paktu Warszawskiego oraz członkowie ich rodzin. Innym, ciekawym przykładem okoliczności współczesnego zaniku osadnictwa może być wieś Kuców, założona w XIX wieku przez osadników czeskich (Dronka 1999). Osada praktycznie zniknęła z powierzchni ziemi do początku lat 90 . XX wieku w związku z rozszerzeniem eksploatacji węgla brunatnego metodą odkrywkową w rejonie Kleszczowa. Dotychczasowe rozważania klasyfikacyjno-empiryczne miały na celu wykazać zróżnicowany zakres przyczyn zaginięcia osad w sensie absolutnym. Rekapitulując ten wątek warto zauważyć, zgodnie z refleksją wyrażoną przez K. Scharlaua (1938), że opustoszenie jest często uwarunkowane oddziaływaniem wielu czynników, których koincydencja może decydować dopiero o zaniku osadnictwa na danym obszarze.

\section{Uwagi metodyczne na temat identyfikacji i lokalizacji osad zaginionych}

W świetle przeprowadzonych badań ujawnia się wyraźnie zróżnicowanie metodyczne w zakresie identyfikacji i ustalania lokalizacji osad zaginionych. Fundamentalne znaczenie wykazuje oczywiście analiza źródeł historycznych, oparta

${ }^{25}$ Dokumenty kujawskie i mazowieckie przeważnie z XIII wieku, Wyd. B. Ulanowski, Archiwum Komisji Historycznej, t. 4, Kraków 1887, s. 217.

${ }^{26}$ Polska XVI wieku..., op. cit., s. 194.

${ }^{27}$ Lustracja województw wielkopolskich i kujawskich 1659-1665, cz. 2: Województwa sieradzkie, tęczyckie, brzesko-kujawskie, inowrocławskie i ziemia dobrzyńska, Wyd. Z. Górski, J. Pakulski, A. Tomczak, Toruń 1996, s. 164, 186. 
na szerokiej kwerendzie dokumentów i materiałów opisowych. W większości przypadków pozwalają one z sukcesem rozpoznać osady, które na różnym etapie swego funkcjonowania uległy zanikowi. Nie zawsze jednak, o czym wspomniano, dają możliwość jednoznacznego określenia przyczyny opustoszenia. Istnieje za to duża szansa, by w sposób uprawniony rozróżnić osady zaginione w wyniku okresowej lub trwałej depopulacji od osad zaginionych pozornie w wyniku inkorporacji, konsolidacji lub denominacji na płaszczyźnie osadniczej. W sukurs przychodzą w tym przypadku metody retrogresywno-toponimiczne, bazujące na ewolucji nazw własnych miejscowości lub ich części. Ogromną rolę pomocniczą odgrywają również historyczne mapy topograficzne oraz wielkoskalowe plany archiwalne, dzięki którym możliwa jest w wielu spornych sytuacjach interpretacja zgromadzonego materiału pod kątem przeprowadzenia rozstrzygającego wnioskowania. Oddzielną grupę stanowią metody charakterystyczne dla badań archeologicznych, które pozwalają na weryfikację spostrzeżeń geograficzno-historycznych i mają zasadnicze znaczenie z punktu widzenia identyfikacji zaniku osadnictwa we wczesnym średniowieczu, tj. w okresie poprzedzającym tworzenie na masową skalę źródeł pisanych.

Zupełnie inną kwestią jest natomiast ustalenie lokalizacji zaginionych osad. Często nastręcza ono badaczom wielu trudnych do rozstrzygnięcia problemów. Dla przykładu na obszarze Lubelszczyzny lokalizacji pewnej dokonano w 140 przypadkach, w dalszych 72 ma ona charakter hipotetyczny, 37 osad zaś nie udało się zlokalizować w ogóle (Wojciechowski i in. 1986, s. 14). Prób lokalizacji można dokonać na wiele sposobów. Jeśli osada zaginęła dopiero w XIX wieku, jak chociażby w przypadku Dobiesławic, położonej w przedrozbiorowym powiecie orłowskim, do ustalenia jednoznacznej lokalizacji posłużyć mogą mapy historyczne, gdyż wieś jest oznaczona na mapie W. Chrzanowskiego ${ }^{28}$. W przypadku wcześniejszego zaniku zmuszeni jesteśmy stosować metody retrogresywne oparte na źródłach pisanych oraz tzw. nazwach polnych. Można wówczas dokonać prób lokalizacji przybliżonej (niepewnej), dzięki opisom granic wsi i dóbr ziemskich, czego egzemplifikacją może być wieś Bielawki w par. Leźnica Wielka zlokalizowana na podstawie opisu wsi, z którymi graniczyła w XV wieku (Chłapowski 1998, s. 46). Często jednak dysponujemy tylko informacjami na temat przynależności parafialnej osady, które są niewystarczające z punktu widzenia choćby hipotetycznej lokalizacji. W tej sytuacji satysfakcjonujące rozwiązanie problemu mogą przynieść dopiero wyniki badań archeologicznych.

${ }^{28}$ Karta dawnej Polski z przyległemi okolicami krajów sąsiednich, W. Chrzanowski, Paryż 1859, 1:300 000, Biblioteka Narodowa, sygn. BN ZZK 20750-20798. 


\section{Podsumowanie}

Przeprowadzone studia miały na celu przedstawienie dyskusji naukowej dotyczącej osad zaginionych w Polsce na tle europejskim. W artykule dokonano próby uściślenia terminologii w tym zakresie oraz klasyfikacji analizowanych zjawisk na gruncie badań geograficzno-historycznych osadnictwa. Na podstawie dostępnej literatury przedmiotu oraz dzięki podjętej kwerendzie materiałów źródłowych ukazano dylematy metodyczno-empiryczne dotyczące kwestii różnych typów osad zaginionych, określenia okresu ich zaniku i ewentualnej sukcesji osadniczej, a ponadto ustalenia przyczyn opustoszenia oraz metod ich lokalizacji w przestrzeni geograficznej. Autor artykułu chciałby wyrazić nadzieję, że dokonana konceptualizacja stanowić będzie swoistą inspirację dla kolejnych badaczy podejmujących omawianą problematykę w przyszłości.

\section{LITERATURA}

Abel W., 1943, Die Wüstungen des ausgehenden Mittelalters: Ein Beitrag zur Siedlungsund Agrargeschichte Deutschlands, Jena.

Abel W. (Hg.), 1967, Wüstungen in Deutschland. Ein Sammelbericht, Frankfurt am Main. Allison K.J., 1970, Deserted Villages, London.

Allison K.J., Beresford M.W., Hurst J.G., 1965, The Deserted Villages of Oxfordshire, Department of English Local History Occasional Papers, 17, Leicester.

Allison K.J., Beresford M.W., Hurst J.G., 1966, The Deserted Villages of Northamptonshire, Department of English Local History Occasional Papers, 18, Leicester.

Antoniadis-Bibicou H., 1965, Villages désertés en Grèce, [w:] Romano R. et Courbin P. (eds), Villages désertés et histoire économique. XIe-XVIIIe siecle. Problemes histoire agraire et démographique, Paris, s. 343-418.

Arnold S., 1951, Geografia historyczna, Warszawa.

Beresford M.W., 1951, The Lost Villages of Medieval England, „Geographic Journal”, 117, s. $129-149$.

Beresford M.W., 1954, The Lost Villages of England, London.

Beresford M.W., 1954, The Lost Villages of Yorkshire, „Yorkshire Archaeological Journal", 38, s. 280-309.

Bjørkvik H., 1965, Villages désertés: bilan de la recherche en Norvège et en Suède, [w:] Romano R. et Courbin P. (eds), Villages désertés et histoire économique. XIe-XVIIIe siecle. Problemes histoire agraire et démographique, Paris, s. 581-606.

Born M., 1972, Wüstungsschema und Wüstungsquotient, „Erdkunde”, 26, s. 208-218.

Born M., 1979, Objektbestimmung und Periodisierungen als Problem der Wüstungs-forschung. Dargelegt unter vornehmlichem Bezug auf neuere Untersuchungen, „Geographische Zeitschrift", 67, s. 43-60.

Bujak F., 1908, Z dziejów wsi polskiej (Wsi zamku oświęcimskiego na początku XVI w.), Studia ku czci prof. W. Zakrzewskiego, Kraków.

Burleigh G.R., 1973, An Introduction to Deserted Medieval Villages in East Sussex, „Sussex Archaeological Collections", 111, s. 45-83. 
Cabrillana N., 1965, Villages désertés en Espagne, [w:] Romano R. et Courbin P. (eds), Villages désertés et histoire économique. XIe-XVIIIe siecle. Problemes histoire agraire et démographique, Paris, s. 461-514.

Černý E., 1979, Zaniklé středověké osady a jejich plužiny. Metodika historickogeografického výzkumu v oblasti Drahanské vrchoviny, Studie ČSAV č. 1, Praha.

Černý E., 1992, Výsledky výzkumu zaniklých středověkých osad a jejich plužina, Brno.

Chevallier R., 1965, Photographie aérienne et villages désertés, [w:] Romano R. et Courbin P. (eds), Villages désertés et histoire économique. XIe-XVIIIe siecle. Problemes histoire agraire et démographique, Paris, s. 63-82.

Chłapowski K., 1998, Lokalizacja miejscowości, [w:] Rutkowski H. (red.), Atlas Historyczny Polski. Województwo sieradzkie $i$ województwo tęczyckie $w$ drugiej połowie XVI wieku, cz. 2, Warszawa, s. 42-49.

Coulet N., 1973, Encore les villages disparus: dépeuplement et repeuplement autour d'Aix-en-Provence (XIVe-XVe siècle), „Annales. Économies, Sociétés, Civilisations”, 6, s. 1463-1483.

Courbin P., 1965, Méthodologie des fouilles de villages disparus en France (prospection et implantation), „Annales. Économies, Sociétés, Civilisations”, 20 (2), s. 243-256.

Davison A., 1996, Deserted Villages in Norfolk, North Walsham.

Démians d'Archimbaud G., 1965, Archéologie et villages désertés en Provence, [w:] Romano R. et Courbin P. (eds), Villages désertés et histoire économique, XIe-XVIIIe siecle. Problemes histoire agraire et démographique, Paris, s. 287-302.

Denecke D., 1985, Wüstungsforschung als siedlungsräumliche Prozess- und Regressionsforschung, ,Siedlungsforschung”, 3, s. 9-35.

Driver L., 2006, The Lost Villages of England, London.

Dronka T., 1999, Wsie osadników niemieckich i czeskich $w$ dawnym powiecie łaskim, „Na Sieradzkich Szlakach", 3-4, s. 7-13.

Duby G., 1965, Démographie et villages désertés, [w:] Romano R. et Courbin P. (eds), Villages désertés et histoire économique, XIe-XVIIIe siecle. Problemes histoire agraire et démographique, Paris, s. 13-24.

Dyer C., 1982, Deserted Medieval Villages in the West Midlands, „Economic History Review", 35, s. 19-34.

Dyer C., Jones R. (eds.), 2010, Deserted Villages Revisited, Hatfield.

Fehn K., 1983, Die historischgeographische Wüstungsforschung in Mitteleuropa, „Mittelalterliche Wüstungen in Niederösterreich, Studien und Forschungen aus dem Niederösterreichischen Institut für Landeskunde", 6, Wien, s. 1-21.

Figlus T., 2011, Rozwój osadnictwa wiejskiego w województwie łęczyckim w XV i XVI wieku, Praca magisterska napisana w Katedrze Historii Średniowiecznej UŁ pod kierunkiem T. Nowaka, mps w Bibliotece Instytutu Historii UŁ, Łódź.

Figlus T., 2013, Morfogeneza wsi na obszarze Polski Środkowej, Rozprawa doktorska wykonana pod kierunkiem M. Kuleszy, mps w Bibliotece Uniwersytetu Łódzkiego, Łódź.

Figlus T., 2015, Geneza i zmiany struktury społeczno-gospodarczej osadnictwa wiejskiego w dobrach królewskich na obszarze przedrozbiorowego powiatu szadkowskiego, „Biuletyn Szadkowski”, 15, s. 89-108.

Gieysztor A., 1965, Villages désertés: bilan de la recherche polonaise, [w:] Romano R. et Courbin P. (eds), Villages désertés et histoire économique. XIe-XVIIIe siecle. Problemes histoire agraire et démographique, Paris, s. 607-612. 
Głuszak J., 1986, Jeziorsko - geneza i koncepcja zbiornika, „Gospodarka Wodna”, 8, s. $183-184$.

Goldberg J., 1957, Osadnictwo olęderskie $w$ dawnym województwie łęczyckim i sieradzkim, „Zeszyty Naukowe Uniwersytetu Łódzkiego”, Seria I, Nauki Humanistyczno-Społeczne, 5, s. 67-110.

Górska-Gołaska K., 2003, Słownik historyczno-geograficzny ziem polskich w średniowieczu, [w:] Kuczyński S. (red.), Instytut Historii Polskiej Akademii Nauk 1953-2003, Warszawa, s. 137-150.

Grabowski S., 2006, Z dziejów gminy Dźwierzuty, „Rocznik Mazurski”, 10, s. 3-6.

Hall J., Hamlin A., 1976, Deserted Medieval Settlements in Devon, „The Devon Historian", 13, s. 2-7.

Heike O., 1979, 150 Jahre Schwabensiedlungen in Polen 1795-1945, Leverkusen.

Hensel H., 1960, Remarque sur les villages desertes en pays slaves, „Slavia Antiqua”, 7, s. $307-392$.

Humm A., 1971, Villages et hameaux disparus en Basse-Alsace: contribution à l'histoire de l'habitat rural (XIIe-XVIIIe siècles), Strasbourg.

Inglot S., 1927, Stosunki społeczno-gospodarcze ludności $w$ dobrach biskupstwa włocławskiego w pierwszej połowie XVI wieku, „Archiwum Towarzystwa Naukowego we Lwowie", dział 2, III, 4, s. 1-95.

Jäger H., 1979, Wüstungsforschung in geographischer und historischer Sicht, [in:] Jankuhn H., Wenskus R. (Hrsg.), Geschichtswissenschaft und Archäologie, „Vorträge und Forschungen", 22, Sigmaringen, s. 193-241.

Janssen W., 1968, Methodische Probleme archäologischer Wüstungsforschung, „Nachrichten der Akademie der Wissenschaften in Göttingen", Philologisch-historische Klasse, 2, s 29-56.

Klapisch-Zuber C., Day J., 1965, Villages désertés en Italie, [w:] Romano R. et Courbin P. (eds), Villages désertés et histoire économique. XIe-XVIIIe siecle. Problemes histoire agraire et démographique, Paris, s. 419-460.

Kłos S., 2010, Krajobrazy nieistniejących wsi, Rzeszów.

Kossmann E.O., 1942, Die Anfänge des Deutschtums im Litzmannstädter Raum, Hauländer-und Schwabensiedlung im östlichen Wartheland, Leipzig.

Krenzlin A., 1959, Das Wüstungsproblem im Lichte der ostdeutschen Siedlungsforschung, „Zeitschrift für Agrargeschichte und Agrarsoziologie”, 7, s. 153-169.

Latocha A., 2013, Wyludnione wsie w Sudetach. I co dalej?, „Przegląd Geograficzny”, $85(3)$, s. 373-396.

Leingärtner G., 1956, Die Wüstungsbewegungen im Landgericht Amberg vom ausgehenden Mittelalter bis zur Neuorganisation des Landgerichts im Jahre 1803, „Münchener Historische Studien", Abteilung bayerische Geschichte, Bd. 3, München.

Mielczarski S., Szaflik J.R., 1956, Zagadnienie łanów pustych w Polsce w XV i XVI wieku, „Studia i Materiały do Dziejów Wielkopolski i Pomorza”, 1(2), s. 55-103.

Mortensen H., Scharlau K., 1949, Der siedlungskundliche Wert der Kartierung von Wüstungsfluren, ,Nachrichten der Akademie der Wissenschaften in Göttingen”, Philologisch-historische Klasse, s. 303-331.

Muir R., 1982, The Lost Villages of Britain, London.

Nekuda V., 1975, Pfaffenschlag. Zaniklá středověká ves u Slavonic, Brno. 
Nowak T. Adamek R., 2000, Zarys dziejów Dobronia i okolicznych miejscowości do 1939 roku (wchodzacych w skład obecnej gminy Dobroń), Łask-Dobroń.

Nowak T., 2011, Kutno i Łąkoszyn do schyłku XVI w., [w:] Szymczak J. (red.), Kutno poprzez wieki, t. 1, Kutno-Lódź.

Oosthuizen S., 2009, The Deserted Medieval Settlements of Cambridgeshire: A Gazetteer, „Medieval Settlement Research”, 24, s. 14-19.

Pałucki W., 1967, Atlas historyczny ziem polskich drugiej połowy XVI wieku, „Kwartalnik Historyczny", 74(1), s. 99-110.

Peltre J., 1966, Un bilan des recherches européennes sur les villages désertés, „Revue Géographique de l'Est", 6(1), s. 115-126.

Pesez J.M., 1965, Sources écrites et villages désertés, [w:] Romano R. et Courbin P. (eds), Villages désertés et histoire économique. XIe-XVIIIe siecle. Problemes histoire agraire et démographique, Paris, s. 83-102.

Pesez J.M., Le Roy Ladurie E., 1965, Les villages désertés en France: vue d'ensemble, „Annales. Économies, Sociétés, Civilisations”, 20(2), s. 257-290.

Piecuch A., Harkawy A., Janowska-Harkawy M., 2013, Opuszczone wsie ziemi gorlickiej, Warszawa.

Pohlendt H., 1950, Die Verbreitung der mittelalterlichen Wüstungen in Deutschland, Göttingen.

Ponsot P., 1968, Villages désertés et histoire économique. XI-XVIII siecle. Problemes histoire agraire et démographique, „Annales. Économies, Sociétés, Civilisations”, $23(3)$, s. 663-669.

Ramskou T., 1965, Villages désertés: bilan de la recherche danoise, [w:] Romano R. et Courbin P. (eds), Villages désertés et histoire économique. XIe-XVIIIe siecle. Problemes histoire agraire et démographique, Paris, s. 613-618.

Roncayolo M., 1965, Géographie et villages désertés, [w:] Romano R. et Courbin P. (eds), Villages désertés et histoire économique. XIe-XVIIIe siecle. Problemes histoire agraire et démographique, Paris, s. 25-48.

Rusiński W., 1957, Uwagi o zniszczeniach po wojnach z połowy XVII w., [w:] Lepszy K. (red.), Polska w okresie drugiej wojny północnej 1655-1660, t. 2, Warszawa, s. $427-434$.

Rusiński W., 1961, Pustki - problem agrarny feudalnej Europy, „Roczniki Dziejów Społecznych i Gospodarczych", 23, s. 9-47.

Rutherford-Davies K., 1973, The Deserted Medieval Villages of Hertfordshire, Chichester.

Rymar E., 1971, Zaginione i opustoszałe osady wiejskie na obszarze powiatu pyrzyckiego w'średniowieczu, „Zeszyty Pyrzyckie”, 4, s. 139-156.

Scharlau K., 1933, Beiträge zur geographischen Betrachtung der Wüstungen, „Badische Geographische Abteilungen", 10, Freiburg.

Scharlau K., 1938, Zur Frage des Begriffes ,Wüstung, „Geographische Anzeiger”, 39, s. $247-252$.

Srogosz T., 1990, Ekonomiczne i społeczne następstwa przemarszów oraz stacjonowania wojsk własnych na terenie województw tęczyckiego, sieradzkiego oraz ziemi wieluńskiej w XVII wieku, „Acta Universitatis Lodziensis. Folia Historia”, 37, s. 3-33.

Stępniewski M., Szambelan Z., 2009, Rozwój terytorialny Łodzi w świetle dokumentów iźródeł kartograficznych, „Rocznik Łódzki”, 56, s. 37-50. 
Szaflik J.R., 1952, Wtórne lokacje na łanach opuszczonych w Polsce w XV i XVI wieku. Wtórne lokacje na łanach opuszczonych $w$ Polsce $w$ XV $i$ XVI wieku, „Annales Universitatis Mariae Curie-Skłodowska”, Sectio F, Nauki Filozoficzne i Humanistyczne, 7, s. 171-200.

Szmytkie R., 2008, Nieistniejace wsie w Sudetach, [w:] Kulesza M. (red.), Czas $i$ przestrzeń $w$ naukach geograficznych. Wybrane problemy geografii historycznej, Łódź, s. 225-242.

Tyszkiewicz J., 2014, Geografia historyczna. Zarys problematyki, Warszawa.

Vigar J., 1994, Lost Villages of Sussex, Wimborne.

Walawender A., 1932-35, Kronika klęsk elementarnych $w$ Polsce $i$ w krajach sasiednich w latach 1450-1586, t. 1: Zjawiska meteorologiczne i pomory, t. 2: Zniszczenia wojenne i pożary, Lwów.

Warężak J., 1929, Rozwój uposażenia arcybiskupstwa gnieźnieńskiego w średniowieczu $z$ uwzględnieniem stosunków gospodarczych w XIV $i$ XV w. Badania dziejów społecznych i gospodarczych, 5, Lwów.

Wojciechowski S., 1930, Zaginione osady w Lubelskiem, „Pamiętnik Lubelski”, 1, s. 116-169.

Wojciechowski S., Sochacka A., Szczygieł R., 1986, Dzieje Lubelszczyzny, t. 4: Osady zaginione i o zmienionych nazwach historycznego województwa lubelskiego, Warszawa.

Wolski J., 2007, Przekształcenia krajobrazu wiejskiego Bieszczadów Wysokich w ciagu ostatnich 150 lat, „Prace Geograficzne”, 214, Warszawa.

Woźniak K.P., 2013, Niemieckie osadnictwo wiejskie między Prosna a Pilica $i$ Wista od lat 70. XVIII wieku do 1866 r. Proces i jego interpretacje, Łódź.

Zawadzki W., 1963, Polska stanisławowska w oczach cudzoziemców, t. 1, Warszawa.

\section{Materiały źródłowe}

Archiwum Główne Akt Dawnych w Warszawie, Zbiór kartograficzny, sygn. 326-17.

Archiwum Państwowe w Łodzi, Zbiór kartograficzny, Mapa rozwoju terytorialnego Łodzi w latach 1821-1915, opracowana w Oddziale Pomiarów Magistratu m. Łodzi, sygn. 2917.

Dokumenty kujawskie i mazowieckie przeważnie z XIII wieku, Wyd. B. Ulanowski, Archiwum Komisji Historycznej, t. 4, Kraków 1887.

Jana Łaskiego Liber beneficiorum archidyecezyi gnieźnieńskiej, t. 2, Wyd. J. Łukowski, Gniezno 1881.

Joannis Dtugosz Liber beneficiorum dioecesis cracoviensis, t. 3, Opera omnia, t. 9, Wyd. L. Łętowski, Kraków 1864.

Karta dawnej Polski z przyległemi okolicami krajów sąsiednich, W. Chrzanowski, Paryż 1859, 1:300 000, Biblioteka Narodowa, sygn. BN ZZK 20750-20798.

Kodeks dyplomatyczny Wielkopolski, t. 2, Wyd. I. Zakrzewski, Poznań 1878.

Księga wizyt dóbr Pabianice należacych do uposażenia kapituly krakowskiej 1496-1540, Wyd. B. Ulanowski, Kraków 1921.

Księgi sądowe łęczyckie od 1385 do 1419, cz. 1, [w:] Teki A. Pawińskiego, t. 3, Warszawa 1897. 
Liber beneficiorum dioecesis posnaniensis anni 1510, Wydawnictwa źródłowe Komisji Historycznej PTPN, 10, Wyd. J. Nowacki, Poznan 1950.

Lustracja województw wielkopolskich i kujawskich 1564-1565, cz. 2, Wyd. A. Tomczak, Bydgoszcz 1963.

Lustracja województw wielkopolskich i kujawskich 1659-1665, cz. 2: Województwa sieradzkie, łęczyckie, brzesko-kujawskie, inowrocławskie i ziemia dobrzyńska, Wyd. Z. Górski, J. Pakulski, A. Tomczak, Torun 1996.

Lustracja województw wielkopolskich i kujawskich 1789, cz. 3: Województwa tęczyckie i brzesko-kujawskie, Wyd. A. Tomczak, Z. Kędzierska, Warszawa-Poznań-Toruń 1977. Matricularum Regni Poloniae summaria, t. 1, Wyd. T. Wierzbowski, Warszawa 1905. Mikołaja Kopernika lokacje łanów opuszczonych, Wyd. Marian Biskup, Olsztyn 1970. Monumenta Medii Aevi Historica res gestas Poloniae illustrantia, t. 13, Acta capitulorum nec non iudiciorum ecclesiasticorum selecta, Wyd. B. Ulanowski, Kraków 1894.

Obwieszczenie Wojewody Lódzkiego z dnia 11 maja 1935 roku o stwierdzeniu i ustaleniu granic miasta Łodzi, Łódzki Dziennik Wojewódzki, 1935, nr 10, poz. 151.

Polska XVI wieku pod względem geograficzno-statystycznym opisana przez Adolfa Pawińskiego, t. 2: Wielkopolska, [w:] Źródla Dziejowe, t. 13, Warszawa 1883.

Pommersches Urkundenbuch, Bd. 5, Wyd. O. Heinemann, Stettin 1903.

Rozporzadzenie Rady Ministrów z dnia 4 lipca 1929 roku o zmianie granic miasta Kutna, w powiecie kutnowskim, województwie warszawskim, Dz.U., 1929, nr 52, poz. 421.

Special Karte von Südpreussen, D. Gilly, Berlin 1802-1803, 1:150000, Biblioteka Uniwersytetu Łódzkiego, sygn. K 159.

Uchwata Rady Narodowej Miasta Łodzi nr XXVH/161/87 z dnia 29 czerwca 1987 roku w sprawie zmiany granic miasta Lodzi, M.P., nr 25, poz. 205 z dnia 4 września $1987 \mathrm{r}$.

Visitationes bonorum archiepiscopatus necnon capituli Gnesnensis saeculi XVI, Wyd. B. Ulanowski, Kraków 1920.

\section{PROBLEM OF LOST SETTLEMENTS IN THE LIGHT OF HISTORICO-GEOGRAPHICAL STUDIES AN ATTEMPT OF THEORETICAL CONCEPTUALIZATION AND SELECTED METHODICAL AND EMPIRICAL ISSUES}

Abstract The article presents the problem of settlement disappearance. At the stage of analysis of historico-geographical research it was possible to identify some terminological chaos, which encouraged the author to make an attempt to systematize terms and to propose clear definitions. Among the all disappeared settlements one can distinguish two basic categories: practically deserted settlements, which were completely abandoned as a result of extreme natural phenomena, repercussions of wars and natural disasters, as well as transformation of the economic structure. One can also identify formally lost settlements, accompanied by the disappearance of the proper name as a result of legal and administrative processes of consolidation, incorporation to the 
nearby town or phenomenon of denomination. In the context of the presented results of empirical studies author discussed some methodological problems related to the availability of the source material, as well as techniques to determine the period and decay time of settlement, to identify the phenomenon of settlement succession after temporary total depopulation, to specify the circumstances of desolation and indicate the exact or approximate location of the disappeared settlements.

Keywords Deserted settlements, settlement emptiness, historical geography, rural settlement.

Dr Tomasz Figlus Katedra Geografii Politycznej i Studiów Regionalnych Wydział Nauk Geograficznych Uniwersytet Łódzki 